DOI https://doi.org/10.36059/978-966-397-196-4/39-56

\title{
EUROENGLISH AS A FEATURE OF LYRIC DISCO TEXTS
}

\section{Kuzmenko A. O.}

\section{INTRODUCTION}

"Never before has a language been used as a lingua franca by so many people in so many parts of the world. English is so remarkable in having more non-native than native speakers". Nowadays English has a dominant position in technology progress, business and trade spheres, sport and education, medicine, policy, science and art. Such popularity gives rise to the language modifications and appearance of its different numerous variants, which save main features of titanic variants like British English and American English as well as brings specific culturallinguistic peculiarities of a non-native English speaker. One of modern variants is Euro-English which has its unique characteristics. It has simplified forms of both British and American variants that are influenced by European languages, culture ${ }^{2}$, policy and history. B. Carstensen ${ }^{3}$ was one of the first linguists who introduced the term 'Euro-English' more than 40 years ago. Since then lots of scientists have defined the term 'Euro-English' as:

- English of all the European Union countries except the United Kingdom and Ireland ${ }^{4}$;

- a potential independent variety of English in Europe ${ }^{5}$;

- a modern variant of English in Europe ${ }^{6}$.

1 Trudgill P. Sociolinguistic Variation and Change. Edinburgh: Edinburgh University Press, 2002. 224 p. - P. 151.

${ }^{2}$ Кочетова М.Г. Лингвокультурная значимость английского языка в Европе. Филологические науки. Вопросы теории и практики. Тамбов: Грамота, 2015. № 8. Ч. 2. С. 89.

3 Carstensen B. Euro-English. Linguistics across historical and geographical boundaries. New York: de Gruyter. 1986. Vol. 2. P. 832.

${ }^{4}$ McArthur T. Oxford guide to World English. Oxford: Oxford university press, 2002. P. 11.

${ }^{5}$ Mollin S. Euro-English. Assessing variety status. Tubingen: Narr, 2006.

${ }^{6}$ Кочетова М.Г. Евро-английский язык как межнациональный феномен в контексте европейской мультилингвальности. Филологические науки. Вопросы теории и практики. Тамбов: Грамота, 2015. № 9(51). Ч. 2. С. 108-110. 
Although such scientists as K. Melezhik ${ }^{7}$ and S. Vlasenko ${ }^{8}$ state that this variant became widespread with the appearance of the European Union, its economy and policy relations, we are eager to suppose that one of the main factors that popularize new tendencies more quickly and wider is culture, especially lyric texts such as songs that are transmitted all over the world with the help of television, radio, social networks and the Internet.

D. Crystal sees a positive aspect for the global culture as a whole here, because any lyric text is fulfilled with the soul of freedom, disobedience and progress for the younger generation'. According to A.N. Polezhaev, lyric text should be considered as a component of cultural space, which has a great influence on its addressees; a lyric text is capable of both powerful and destructive actions on a language and its speakers: the ability to form a bank of linguistic means that are perceived by native speakers as a model that can later be used to express one's own thoughts and emotions ${ }^{10}$.

According to D. Crystal, over $90 \%$ of bands and solo performers of contemporary lyrics sing in English despite their native language.

This work deals with the lyric text of Disco, which has occupied one of the leading positions in the history of song culture. Disco is a style that originated in Germany in the 60-70s, has a focus on maximizing the convergence of art with life; it reflects the partnership / relationship between the artist and the recipient ${ }^{11}$. The performers and authors of these lyric texts are non-native English speakers, but they are fluent in it and they come from Europe.

Thus, the object of the work is lyric disco text (LDT), while the subject is its specific use of Euro-English. The main tasks are to characterize lexical peculiarities of Euro-English in LDT, to identify its

7 Melezhik K. The problem of the Euro-English language in international communication. Baltic Humanitarian Journal. 2017. Vol. 6. № 4(21). P. 124-127.

8 Власенко С.В. Евроанглийский язык и проблемы англо-русского взаимодействия на пространстве профессиональной коммуникации. URL : https://www.hse.ru/data/2011/05/11/1213461263/Власенко\%20СВ_ЕВРОАНГЛИЙ СКИЙ\%20-\%20Доклад\%20РГГУ_окт2010.pdf

${ }^{9}$ Crystal D. English as a Global language. Cambridge: Cambridge University Press, 1997. P. 47.

10 Полежаева А.Н. проблемы современного песенного текста: лингвоэкологический аспект: дис. ... к.филол.н.. Самара, 2005. 183 с.

11 Бартош Н.Ю. История культуры Западной Европы (XX век). URL : http://window.edu.ru/resource/251/28251 
distinctive features on phonetic level and to describe the morphosyntax arrangement on the materials of the most popular artist's LDT. Disco style is mostly presented by Baby's Gang, Bad Boys Blue, Blue System, C.C.Catch, Click, Danuta, Desireless, Fancy, Fox the Fox, F.R. David, Icehouse, Joy, Kylie Minougue, Laid Back, Lian Ross, Modern Talking, Patty Ryan, Pet Shop Boys, Samantha Fox, Sabrina, Sandra, Secret Service, Silent Circle, Yello and others whose lyrics have become the material to investigate.

Specific techniques and methods are determined by the tasks and material to be researched. They are the following: induction and deduction, analysis and synthesis, abstraction and concretization; processing and interpretation methods; the procedures of qualitative calculations and the method of integral choice.

\section{Euro-English Lexical Characteristics of Lyric Disco Texts}

Reflecting human's attraction to art as an identification of the needs for experiencing significant moments and the figurative-symbolic representation, LDT immerses the addressee in some "second reality", where the self-expression and self-knowledge of the human soul takes place $^{12}$. As a poetic work, LDT appeals to emotions. Therefore, in most cases $(95 \%)$, its content tends to cover intergender relationships, usually with a passion for their participants' feelings. This makes English LDT "light" in its content with a great influence on the auditory. Also, it affects the usage of specific lexical units.

It is a common thing to come across Americanisms or verbalization of American realities. American spoken English appears in different types of word-mergings. Such merging can happen of two types:

- Type 1 - a content word + an auxiliary part of speech wanna, gonna, gotta:

I wanna kiss you, kiss you

I wanna miss you, miss you

I never want to lose your heart

(Blue System "Sorry little Sarah");

Merging of Type 1 is present in $93 \%$ of all possible mergings in LDT. In these cases merging happens with a content word that is a verb and an

12 Панченко В.А. Песня как объект лингвистических исследований: краткий обзор. С. 140.
Feel the time is passing

And it's moving much too fast

Gonna try to use it

Make it last

(Fancy "Save the moments"). 
auxiliary part of speech that is a particle: wanna $=$ want to and gonna $=$ going to. As an exception it is also used gotta = got to in LDT:

You only gotta reach out

Reach out and taste my loving.

Want you so | Sunday girl

(Bad Boys Blue "I wanna hear your heartbeat")

Thus, wanna happens twice more often than gonna, that is $70 \%$ and $28 \%$ respectively, while the use of gotta is not preferable $-2 \%$.

- Type 2 - a content word + a content word: gimme etc.

Type 2 is just in $7 \%$ of cases of all possible mergings in LDT. This Type happens by adding a personal pronoun to a verb gimme = give me:

$\mathrm{Hi}$ ! Hi! Hi! We need emotion!

(Love is incurable)

I say Hi! Hi! Hi! Gimme a sign!

We might apologize and we might realize

Hi...Hi...

Hi! Hi! Hi! We need emotion!

(Love is incurable)

I say Hi! Hi! Hi! Gimme a sign!

(Sandra "Hi! Hi! Hi!").

It should be mentioned, that such mergings as don't know $=$ dunno, got you $=$ gotcha, kind of $=$ kinda, trying to $=$ tryna Ta lot of $=$ lotta are not characteristics of Euro-English LDT.

All the mergings in LDT are necessary to make the text more expressive, to keep rhythm and melody and to follow fluent spoken emotional speech.

M. Kochetova ${ }^{13}$, M. Modiano ${ }^{14}$, H. Murray ${ }^{15}$, E. Seymur ${ }^{16}$, S. Simigne Fenyo ${ }^{17}$ and others nominate a line of lexical fulfillment of Euro-English: new creations and pseudocalques; shifts in meaning;

13 Кочетова М.Г. Евро-английский язык как межнациональный феномен в контексте европейской мультилингвальности. Филологические науки. Вопросы теории и практики. Тамбов: Грамота, 2015. № 9(51). Ч. 2. С. 108-110.

${ }^{14}$ Modiano M. A new variety of English. English today. 2001. P. 13-16.

${ }^{15}$ Murray H. Swiss English teachers and Euro-English: Attitudes to a non-naïve variety. Bulletin Suisse de Linguistique Applicee. 2003. P. 147-165.

16 Seymour E. Euro-English: new pidgin? terminologie et Traduction. 2002. P. 22-32

${ }^{17}$ Simigne Fenyo S. The function of the Englishlanguage in the European Union. European integration studies. 2003. P. 53-64. 
extended use of common verbs do, take, put, make; fixed phrases; usage of 'already' as a focus particle; abbreviations and blendings ${ }^{18}$.

Despite the fact that Euro-English LDTs are full of American and British lexical units, these texts are eager to use lexis of Roman origin: eclipse, torment, jealousy, innocent, guarantee, innocent, paradise, trance, astray, secret, diamond, circle, dangerous, desire, masquerade, insanity, conquer, eternity, aid, fantasy, sentimental, souvenirs, tenderness, ecstasy, sympathy, rescue, sensation etc.:

Why can't you see me?

(Five, four)

Risk of eclipse,

(Three, two)

If you can't forgive me.

(One, return to zero, return to zero!)

(Sandra "Don't cry")
Big yellow taxi, bring him back to me

Pick yellow taxi, love's guarantee

I know she's a venus in blue jeans

But know, she's a queen of broken dreams

(C.C.Catch "You can't run away from it")

Eclipse is "from Old French eclipse, darkness; from Latin eclipsis; from Greek ekleipsis"19. Venus is "from Latin Venus, in ancient Roman mythology, the goddess of beauty and love, especially sensual love"20; guarantee is from Old French garant - defender, protector, warranty, pledge, justifying evidence" 21 .

Lay back

Back in my tenderness

And take

Take all my sweat caress

You've got all of me

It can't go wrong if you agree

Soon two hearts will beat in ecstasy

(Bad Boys Blue "You're a woman").

Even more there are some incidents of French, Italian, Spanish words, word-combinations, phrases, sentences and micro-texts in Euro-English LDT:

Mon amie, Mon amie $\quad$ Close your eyes - how does it feel?

Won't you take your heartache Can you be sure, will you give in?

${ }^{18}$ Forche Ch.R. On the emerge of Euro-Englih as a potential European variety of English - attitudes and interpritations. Jezikoslovlie. 2013. P.447-478

${ }^{19}$ Online etymology dictionary. URL: etymonline.com

${ }^{20}$ Online etymology dictionary. URL: etymonline.com

${ }^{21}$ Online etymology dictionary. URL: etymonline.com 
from me?

Mon amie, Mon amie I need love,

I need sympathy

(Bad Boys Blue "Mon amie")

C'est toi l et ce soir je te veux

faire l'amour avec toi

je t'aime!

Je sais mon amour

queue tu es le seul pour moi!

A world without you

a world on my own

Without your love my heart will turn to stone.

(Bad Boys Blue "A world without you")

In a world of stone

Crying tears on telephone

Oh my lost night with you

Oh I'd love a rendezvous

I need your kisses

(C.C.Catch "House of mystic lights")
If you do, it's passion

L'amour, toujours l'amour

(Sandra "No taboo")

The bright eyes of the boulevards is shining in your tender eyes

Your perfume is exciting me it's still the same.

Michelle

how I love when we love

and I love when you whisper:

je t'aime Michelle mon amour

is it true do you feel the way I do?

(Bad Boys Blue "A world without you")

You think you know me

But you're wrong

To late for questions

When I'm gone

So if you're hear me I'll explain

I need your confort

Not you're blame

(Sandra "Change your mind")

It can be noticed the dominant use of words that are verbal nominations of the concept LOVE. They are rendezvous, Mon amie, je t'aime, l'amour, Je sais mon amour. The expedient uses his / her mother tongue being in a state of excitement, emotionally encouraged and expressing his / her feelings.

Concretization of emotional-perceptive component, history and detailed elaboration of routine-love collision that are known to each person with his / her thought, attitude and assessment are verbalized in Euro-English LDT:

The night is yours, the night is mine

I beg you baby, take your time

It's like paradise

See your magic eyes

Feel the need in me

The night is yours, the night is mine

I beg your baby, take your time 
Heaven in your eyes

Takes me to the sky

I'm in love with you

(Modern Talking "The night is yours, the night is mine")

It can be interpret as a result of sexual revolution of the West in 19601970 in LDT as all the texts are fulfilled with the topics of society's private life, changing moral orients, seizuring conservative norms, downfall of tabooing intimate subjects and liberalization of sexual views.

As a result of expression of frivolity in LDT the verbal censor in Euro-English is defection:

Lay back

Back in my tenderness

And take

Take all my sweat caress

You've got all of me

It can't go wrong if you agree

Soon two hearts will beat in ecstasy

(Bad Boys Blue "You're a woman")

Thus, LDT demonstrates adequately current state of a language and society which speaks it. Announcement of private relations in LDT is not disgraceful and does not fall out of intimate measures.

Moreover, tender and respective attitude of a non-native English language expedient who is fond of his / her traditions, socio-ethnic foundation is shown in Euro-English by the presentation of culture:

Oh, I make your dreams come true

For a tango it takes two

Oh, call me, please call me

I'm a prisoner of your heart

007 in the dark

Just call me, please call me

A man, a child, oh, in my eyes

I'm hating all these lies

A rainbow is still alive
Hold me in your arms again

Strangers down a lonely lane

We can still survive

Driftwood on the stream of life

Hold me in your arms again

Let me touch your velvet skin

No more lonely nights

On the way of no return

Play me the bolero

(Fancy "Bolero")

Heaven - Bad girls go everywhere")

Tango is a dance that was created by south-east Europeans and soon gained its popularity around Europe; bolero is a Spanish folk dance.

To sum up, there are lots of lexical peculiarities of Euro-English in lyric disco texts. They are Americanisms, lexemes of Roman origin, 
combination of English and Roman languages in one text. Also, lexis demonstrating expression of frivolity, intimate relations is used in lyric disco texts. Sometimes realities of Roman traditions / culture are nominated.

\section{Euro-English Phonology Charm of Lyric Disco Texts}

As we have already mentioned all variants of the English language save both British English and American English features, and phonetics of Euro-English is not an exception.

Phonological characteristics of Euro-English are mentioned by D. Crystal ${ }^{22}$, G. Decsy ${ }^{23}$, J. Jenkins ${ }^{24}$ and others. They are the following: absence of $[\theta]$ or [ð] phoneme; realization of labial-velar approximant $[\mathrm{w}]$ as [v]; absence of palatalization of [n] or [t]; regionally different vowel inventories; fixing of the accent on the first syllable; clearer patterns of articulation; slower rate of speech; increasingly syllabletimmed rhythm ${ }^{25}$.

Taking into account LDT it should be mentioned that such peculiarities as its music arrangement dictates some rules in pronunciation as rhythm can't be denied in songs. Such conditions as titanic variants and rhythm make specific markers in phonic illustration of LDT.

This way, Euro-English in LDT is characterized by:

- merging of lexemes that leads to merging and reduction of sounds;

For Euro-English in LDT it is typical to use Americanisms like wanna, gonna, gotta, gimme and so on. The most popular mergings of lexemes are wanna $=[\mathrm{won} \Lambda]=[$ wont $]+[\mathrm{tu}]$ and gonna $=[\mathrm{g} \circ \mathrm{n} \Lambda]=$ [gəuin] $+[\mathrm{tu}]$, where the preposition is reduced and the second part of the main verb is changed in pronunciation with the help of sound combination $[$ เn $\Lambda]$ :

${ }^{22}$ Crystal D. English as a Global Language. Cambridge: Cambridge University Press. 2003

${ }^{23}$ Decsy G. Europe's linguistic future: the Eurish-problem. Eurasian Studies Year-book. 1993. P. 7-18

24 Jenkins J. English as a lingua franca. Interpretations and attitudes. World Englishes. 2009. P. 2009. P. 200-207

${ }^{25}$ Forche Ch.R. On the emerge of Euro-English as a potential European variety of English - attitudes and interpritations. Jezikoslovlie. 2013. P. 447-478. 
Do you wanna - sentimental lady

Do you wanna - be my baby

Do you wanna try my heart

Over and over again

(C.C.Catch "Backseat of your cadillac")
Love. There is magic in my hand.

Love.

Gonna give you all I can.

You know how to ride my love.

You have the special way.

Bless me with your touch by night and day

(Bad Boys Blue "Kiss you all over")

- Euro-English simplification of nasal-sound endings in LDT;

It is preferable livin', breakin', feelin', makin', leanin' etc in LDT. This simplification can be explained by the use of the spoken-language style which makes LDT easier for comprehension by different recipients. Non-native speakers are not used to [n] that is why it is changed into [n], especially in the ending -ing $=[$ in $]$ :

Let's make it real tonight

We'll be dancin' to the pale moonlight

Your dreams are real today

And now you gonna stay

(Modern Talking "The night is yours, the night is mine").

- reduction of sounds;

Reduction of sounds can be of three types:

- front-reduction - initial sounds of the word are reduced ('bout, 'cause):

You said: "Take a seat, tell you ...'cause you are young

'bout a golden ring,

You will always be so strong

Married people lack emotion, Hold on tight to your dreams hold love is just a fight..."

(Sandra "Crazy Juliet")

on

You are right, don't give up

(C.C.Catch "Cause you are young")

- middle-reduction - some sounds are omitted in the middle of the word (the're) - they are = the're:

Hey little girl

Don't wanna cause you pain

But the big boys feel no sorrow

Hey little girl

Hey little girl

The're all the same 
But they feel no sorrow

(Sandra "Hey little girl")

- back-reduction - sounds are reduced in the end of the word (and $\left.=a n^{\prime}\right)$ :

An' she knows that it's forever

An' she'll never ever return

(Sandra "Hey little girl")

It is worth mentioning that in measures of one LDT it is possible to come across the convergence of phonetic changes:

Stay,

Why you're tellin' me that you can't

'cause you're the one that I want

You know you're driving me crazy, crazy, crazy, oh

(Fancy "Feedback, feedback")

To sum up, the phonetic peculiarities of Euro-English in LDT are characterized by saving American English variant and rhythm arrangement of the text. Thus, the main features are merging and reduction of sounds. Also, it is presented a simplification of some nasal sounds due to their absence in the language of a non-native Englishspeaker.

\section{Euro-English Morpho-syntax Peculiarities of Lyric Disco Texts}

Euro-English morpho-syntax peculiarities of LTD are also based on mix of the American and British variants of English with European linguo-culture. This can be presented even in frames of one text:

Hey little girl

Don't wanna cause you pain

But the big boys feel no sorrow

Hey little girl

Hey little girl

They're all the same

But they feel no sorrow

There she is inside a train

An' now she's leanin' back

She's got money for one day

An' nothing in the rack

(Sandra "Hey little girl")

The text illustrates the American variant of simplification of toinfinitive construction "Don't wanna cause", the British possessive 
construction "She's got" and Euro-English word order "There she is inside a train".

Prominent linguists define such general characteristics of EuroEnglish grammar as: productive prefix (confix) euro ${ }^{26}$; omission of the third person singular ending $-s$ in verbs ${ }^{27}$; conflation of Past Simple and Present Perfect ${ }^{28}$; conflation of Continuous- and non-Continuous aspect $^{29}$; loss of gerund; regularization of irregular verbs; decrease of prepositional and phrasal verbs; loss of $d o$-support; underuse or overuse of articles ${ }^{30}$; regular plural marker $-s$ for all nouns; plural marker $-s$ with uncountable nouns; of-genitive with animate referent; interchangeability of relative pronouns who and which ${ }^{31}$; use of demonstrative this with both singular and plural nouns; omission of adverb marker -ly; isn't it? as a universal question tag; simplified sentence structure ${ }^{32}$.

As for the LDT, the most common feature is the use of Simple Tenses that is $80 \%$; Continuous Tenses are less productive (12\%) while Perfect and Perfect-Continuous are avoided. It can be explained by difficulty in understanding temporal net of native-English society by the European speaker. Also, there are some tense infractions noticed in LDT:

- Continuous Tenses instead of Simple Tenses. Stative verbs are used in Continuous in the LDT in Euro-English:

Just call me, please call me

A man, a child, oh, in my eyes

I'm hating all these lies

A rainbow is still alive

(C.C.Catch "Good girls go to heaven - Bad girls go everywhere")
I'm a stranger here

You have no heart of stone

I'm feeling so alone

I know what hell is

Reach out-I'll be there

Long as the rose is red

(C.C.Catch "Wild fire")

${ }^{26}$ Simigne Fenyo S. The function of the Englishlanguage in the European Union. European integration studies. 2003. P. 53-64.

${ }^{27}$ Modiano M. A new variety of English. English today. 2001. P. 13-16.

${ }^{28}$ Decsy G. Europe's linguistic future: the Eurish-problem. Eurasian Studies Year-book. 1993. P. 7-18.

${ }^{29}$ Modiano M. Euro-English: A Swedish perspective. English today. 2003. P. 35-41.

${ }^{30}$ Sand A. Shared morpho-syntactic features in contact varieties of English: Article use. World Englishes. 2004. P. 281-298.

31 Seidlhofer B. Towards making 'Euro-English' a linguistic reality. English Today. 2001. P. 14-16.

${ }^{32}$ Decsy G. Europe's linguistic future: the Eurish-problem. Eurasian Studies Year-book. 1993. P. 7-18. 
- Simple Tenses instead of Continuous one. Euro-English allows using the Present Simple Tense for actions happening around the moment of speaking with temporal marker now:

Oh, I need you back here with me yeah

I think you want it too

Now I feed you with a new emotion

Heal you when you cry

I'll be your loving doctor of the night

(Modern Talking "Do you wanna?")

- Past Simple instead of Present Perfect:

You came around here today

And again you were so cold

I could see it in your eyes

When I tried to touch you

I just can't understand

What happened

I just know I love you

(Sandra "Don't be aggressive")

- omitting of auxiliary verbs:

Change your mind

We getting closer

Change your mind

We can closer

(Sandra "Change your mind")

The auxiliary verb "to be" in Present forms (am, is, are) is omitted in Euro-English LDT.

- incorrect verb use in conditional constructions:

If I be sure that I'm born again

Oh, I heard him say: love is a crazy game

(C.C.Catch "Heartbeat city")

Bare infinitive form is used instead of the Present Simple Tense.

- the use of Future Simple Tense in subordinate conditional construction with the conjunction if to form a predicted action or state:

Dreams are made for you and me

No one wants you if you'll be the losing guy

Come on and take my hand

Come on, come on and take my hand

Like a hurricane is coming tonight

Tonight my love is just on your side

You break my heart boy 
My heart boy, tonight

(C.C.Catch "Like a hurricane")

Mixing there is and there are constructions. There is is used with plural subject:

Acting cold but still on fire

Every time you hold my hand

And there's things we did together

That we planned

(Fancy "Save the moment")

Informal grammar dialect of negative form ain' $t=i$ s not, are not, am not, will not, have not, has not. It makes LDT more dynamic and rhythmic:

Talk to me - want my love.

Talk to me - but not that stuff

You ain't get enough using my love.

You call for me

again l see

(Sandra "In the heat of the night")

Wrong use of auxiliary words in the third person singular:

He don't wanna lose

Baby, baby, it's a simply news

Come

on, baby, keep your hands of him

In the gipsy night

(C.C.Catch "Heaven and hell")

Another characteristic of Euro-English in LDT is loss of subject. It is prevalent to omit the first person singular pronoun $I$ in dialogically directed speech with the you-referent or the third person singular pronoun it in impersonal sentences. The pronouns are usually understood contextually in LDT:

Don't know where you've been last night,

don't know where to go,

I hope that you're alright, walk an endless road,

Can you see me?

$<\ldots>$

I hear your laughter, lying by your side,

Won't be cold in here,

Won't be cold in here...

(Sandra "The journey"). 
We cannot deny that these omissions help to keep rhythm and melody of a text which is the main item for lyrics.

Word order in LDT is stipulated by the rhythm and the emphatic accent of the text, that is why there are commonly syntactic infractions:

Save the moment

As we travel down the road

Save the moment

When you follow where I'm going

And through the darkness of the

$\underline{\text { night }}$

On a highway in the light

The moments we're together side by side

(Fancy "Save the moment")

Once in a year I'm looking back, counting the hurts,

Time after time it's been so hard holding my ground,

$<\ldots>$

Oh this lotto game I don't wanna play...

(On the tray),

Just for seven years,

It's the same odd fears in my

heart...

I can understand my blues

(Sandra "On the tray")

Adverbial modifiers of time and / or place are primarily expressed to stress the importance of the information given.

Simplification of reported speech constructions:

Don't know is it wrong, is it right?

Sweet girl, I wanna love you tonight

So take me as your brother and your friend

But first of all I wanna be your man

(Bad Boys Blue "Pretty young girl")

The indirect question is of a wrong word order Don't know is it wrong, is it right? while it should be asked like Don't you know whether it is wrong or right?;

Heartbeat that's emotion

Heartbeat it's devotion

Ever more desire

Tell me is someone who's better

(Sandra "Heartbeat")

Here is a combination of the imperative construction with the interrogation, that should be presented as "tell me if there is someone who's better". Thus, if for reported speech is usually avoided in LDT.

Moreover, the use of indefinite articles with an uncountable noun:

He don't wanna lose

Baby, baby, it's a simply news

Come on, baby, keep your hands of him

In the gipsy night 
(C.C.Catch "Heaven and hell")

Mistaken formation of plural nouns:

The breakup of the world,

Don't cry,

We're gonna save our lifes and time is on my side;

Don't cry,

I'm gonna realize the breakup of the world...

(Baby, please don't cry)

(Sandra "Don't cry")

However, it is not observed such features of Euro-English in LDT as productive prefix euro-; loss of gerund; regularization of irregular verbs; decrease of prepositional and phrasal verbs; loss of do-support; interchangeability of relative pronouns who and which; omission of adverb marker -ly or isn't it? as a universal question tag.

To sum up, morpho-syntax of LDT has its own characteristics deviations from the norm. They are tense conflation, wrong use / omission of auxiliary verbs, their dialect implementation, incorrect formation of conditional and reported speech constructions, loss of subject, wrong word order, marker $-s$ for all plural nouns and overuse of articles.

\section{CONCLUSIONS}

Up-to-date world situation with its political, economical and trade systems gives birth to new variants of world language adopting it to socio-cultural environment of this language users. Euro-English is the result of international communication created by European Union. The popularization of this variant is realized mostly by culture, especially lyrics.

Lyric text of Disco has occupied one of the leading positions in the history of song culture. It has a focus on combination of art with life; it demonstrates relations between the artist and the recipient. The performers and authors of lyric texts are non-native English speakers from Europe, however their English is fluent.

The object of the work is lyric disco text, the subject is the usage of Euro-English. The main tasks are to characterize lexical peculiarities of Euro-English in lyric disco text, to identify its distinctive features on phonetic level and to describe the morphosyntax arrangement. The investigated materials are texts of Baby's Gang, Bad Boys Blue, Blue System, C.C.Catch, Click, Danuta, Desireless, Fancy, Fox the Fox, F.R. David, Icehouse, Joy, Kylie Minougue, Laid Back, Lian Ross, Modern Talking, Patty Ryan, Pet Shop Boys, Samantha Fox, Sabrina, Sandra, 
Secret Service, Silent Circle, Yello and others whose lyrics have been in top song-charts.

It is found out that Americanisms, lexemes of Roman origin, combination of English and Roman languages, lexis demonstrating expression of frivolity are happened in lyric disco texts. Realities of Roman traditions / culture are verbalized.

Moreover, it is researched that the phonetic peculiarities of EuroEnglish in lyric disco texts save the American English variant with its main features as merging and reduction of sounds. A simplification of some nasal sounds due to their absence in the language of a non-native English-speaker appears in lyric disco texts.

Furthermore, morpho-syntax of lyric disco texts has some deviations such as tense conflation, wrong use / omission of auxiliary verbs, their dialect implementation, incorrect formation of conditional and reported speech constructions, loss of subject, wrong word order, marker $-s$ for all plural nouns and overuse of articles.

To conclude, it is perspective to investigate the stylistic arrangement of Euro-English lyrics and to characterize their conceptual area.

\section{SUMMARY}

The article deals with one of the modern variants of the English language, which is popular on the territory of the European Europe. It is characterized its functioning in texts.

This way, the object of the work is lyric disco text and the subject is the specific use of Euro-English. The main tasks are to characterize lexical peculiarities of Euro-English in lyric disco texts, to identify its distinctive features on phonetic level and to describe the morphosyntax arrangement. The most popular texts are presented by Click, Danuta, Desireless, Fancy, Fox the Fox, F.R. David, Icehouse, Joy, Kylie Minougue, Laid Back, Lian Ross, Modern Talking, Patty Ryan, Pet Shop Boys, Samantha Fox, Sabrina, Sandra, Secret Service, Silent Circle, Yello and others whose lyrics have become the material to investigate.

Specific techniques and methods are determined by the tasks and material to be researched. They are the following: induction and deduction, analysis and synthesis, abstraction and concretization; processing and interpretation methods; the procedures of qualitative calculations and the method of integral choice.

There are lots of lexical peculiarities of Euro-English in lyric disco texts: Americanisms, lexemes of Roman origin, combination of English and Roman languages, lexis demonstrating expression of frivolity / 
intimate relations, verbalization of of Roman traditions / cultural realities.

It has been investigated that the phonetic peculiarities of EuroEnglish in lyric disco texts are characterized by saving American English variant and rhythm arrangement of the text. The main features are merging and reduction of sounds. It is also presented a simplification of some nasal sounds due to their absence in the language of a non-native English-speaker.

Morpho-syntax of lyric disco text has its own characteristics deviations from the norm. They are tense conflation, wrong use / omission of auxiliary verbs, their dialect implementation, incorrect formation of conditional and reported speech constructions, loss of subject, wrong word order, marker $-s$ for all plural nouns and overuse of articles.

\section{REFERENCES}

1. Бартош Н.Ю. История культуры Западной Европы (XX век). URL : http://window.edu.ru/resource/251/28251

2. Власенко С.В. Евроанглийский язык и проблемы англорусского взаимодействия на пространстве профессиональной коммуникации. URL : https://www.hse.ru/data/2011/05/11/ 1213461263/Власенко\%20СВ ЕВРОАНГЛИЙСКИЙ\%20\%20Доклад\%20РГГУ_окт2010.pdf

3. Кочетова М.Г. Евро-английский язык как межнациональный феномен в контексте европейской мультилингвальности. Филологические науки. Вопросы теории и практики. Тамбов: Грамота, 2015. № 9(51). Ч. 2. С. 108-110.

4. Кочетова М.Г. Лингвокультурная значимость английского языка в Европе. Филологические науки. Вопросы теории и практики. Тамбов: Грамота, 2015. № 8. Ч. 2. С. 88-90. - С. 89.

5. Панченко В.А. Песня как объект лингвистических исследований: краткий обзор. С. 138-144. С. 140.

6. Полежаева А.Н. проблемы современного песенного текста: лингвоэкологический аспект: дис. ... к.филол.н.. Самара, 2005. $183 \mathrm{c}$.

7. Carstensen B. Euro-English. Linguistics across historical and geographical boundaries. New York: de Gruyter. 1986. Vol. 2. P. 827-835. - P. 832.

8. Crystal D. English as a Global language. Cambridge: Cambridge University Press, 1997. 165 p. - P. 47. 
9. Decsy G. Europe's linguistic future: the Eurish-problem. Eurasian Studies Year-book. 1993. P. 7-18.

10. Forche Ch.R. On the emerge of Euro-Englih as a potential European variety of English - attitudes and interpritations. Jezikoslovlie. 2013. P.447-478

11. Jenkins J. English as a lingua franca. Interpretations and attitudes. World Englishes. 2009. P. 2009. P. 200-207

12. McArthur T. Oxford guide to World English. Oxford: Oxford university press, 2002. 420p. - P.11

13. Melezhik K. The problem of the Euro-English language in international communication. Baltic Humanitarian Journal. 2017. Vol. 6. № 4(21). P. 124-127.

14. Modiano M. A new variety of English. English today. 2001. P. 13-16

15. Modiano M. Euro-English: A Swedish perspective. English today. 2003. P. 35-41. 2006

16. Mollin S. Euro-English. Assessing variety status. Tubingen: Narr,

17. Murray H. Swiss English teachers and Euro-English: Attitudes to a non-naïve variety. Bulletin Suisse de Linguistique Applicee. 2003. P. 147-165.

18. Online etymology dictionary. URL: etymonline.com

19. Sand A. Shared morpho-syntactic features in contact varieties of English: Article use. World Englishes. 2004. P. 281-298.

20. Seidlhofer B. Towards making 'Euro-English' a linguistic reality. English Today. 2001. P. 14-16.

21. Seymour E. Euro-English: new pidgin? terminologie et Traduction. 2002. P. 22-32.

22. Simigne Fenyo $S$. The function of the Englishlanguage in the European Union. European integration studies. 2003. P. 53-64

23. Trudgill P. Sociolinguistic Variation and Change. Edinburgh: Edinburgh University Press, 2002. 224 p. - P. 151.

\section{Information about the author: Kuzmenko A. O.,}

Candidate of Philological Sciences, Docent, Associate Professor at the Social and Humanities Department, Dnipropetrovsk State University of Internal Affairs 26, Haharina str., Dnipro, 49000, Ukraine 